\title{
ANALYSIS OF mRNA TRANSCRIPTS IN CHRONIC MYELOID LEUKEMIA PATIENTS
}

\author{
Rosely de V. Meissner ${ }^{1}$, Dimas T. Covas ${ }^{3}$, Paula M.B. Dias ${ }^{1}$, Fani Job $^{2}$, Márcia Leite $^{2}$ and Nance B. Nardi $^{1}$
}

\begin{abstract}
The nature of BCR/ABL hybrid mRNA was analyzed by RT-PCR in cells from 33 patients (22 males, 11 females) with chronic myeloid leukemia (CML). b3a2 mRNA was found in 14 cases, whereas 13 patients had b2a2 mRNA and six had both kinds of mRNA, with a predominance of the b3a2 type. The type of mRNA present showed no significant correlation with age, hemoglobin level, number of leukocytes and platelets, percentage of blasts or basophils or the presence of splenomegaly at diagnosis. There was also no correlation with sex or duration of the chronic phase. When these results were combined with those reported by other groups, a significant association $(P=0.029)$ was observed for mRNA type vs. sex, with a predominance of men in the groups expressing b2a2 (2.68:1) and b3a2 (1.33:1). We conclude that the classification of patients according to mRNA type does not homogenize the clinical and hematological data within groups, where variance is large, nor does it allow a differentiation between groups.
\end{abstract}

\section{INTRODUCTION}

Chronic myeloid leukemia (CML) is a clonal disease characterized by the presence of the hybrid gene BCR/ ABL, usually located on the Philadelphia chromosome which results from reciprocal translocation between chromosomes 9 and 22. Two principal types of mRNA (b2a2 and $\mathrm{b} 3 \mathrm{a} 2$ ) can be produced from this gene. These transcripts, which can also be co-expressed by alternative splicing, differ by the presence of BCR exon 14 (exon b3 on the hybrid gene). The $210-\mathrm{kDa}$ protein translated from these mRNAs has increased tyrosine kinase activity, which plays a crucial role in leukemogenesis (Shtivelman et al., 1985; Lugo et al., 1990).

Some reports have suggested a role for exon b3 in the evolution of CML (Mills et al., 1991b). The presence of exon b3 has been associated with abnormal blood parameters such as high platelet counts (Inokuchi et al.,1991; Verschraegen et al., 1995; Shepherd et al., 1995), a low percentage of circulating blast cells, and high leukocyte counts (Zaccaria et al., 1995). High leukocytosis is associated with splenomegaly. Elevated platelet counts (cut off $=700,000 / \mu \mathrm{l})$ and an enlarged spleen are correlated with a bad prognosis, whereas the opposite is observed when the percentage of circulating blast cells is low. These three parameters (platelet counts, circulating blast percentage and spleen size) are used to determine the Sokal prognostic index (Sokal et al.,1984). Other studies, however, have not shown any significant association between the type of mRNA and the clinical or laboratory indicators of CML (Fioretos et al., 1993; Zaccaria et al., 1993; Yin et al., 1995). In this study, we used RT-PCR to investigate

\footnotetext{
${ }^{1}$ Departamento de Genética, Universidade Federal do Rio Grande do Sul, Caixa Postal 15053, 91501-970 Porto Alegre, RS, Brasil. Send correspondence to NBN. Fax: +55-51-319-2011. E-mail: nardi@vortex.ufrgs.br ${ }^{2}$ Hospital de Clínicas de Porto Alegre, Porto Alegre, RS, Brasil. ${ }^{3}$ Centro Regional de Hemoterapia Hemocentro, Ribeirão Preto, SP, Brasil.
}

the type of mRNA present in 33 patients with CML and analyzed the correlation between the molecular data and the hematological and clinical findings.

\section{MATERIAL AND METHODS}

\section{Patients and samples}

Peripheral blood was collected from 31 patients with a clinical and cytogenetic diagnosis of CML, and from two patients with only a clinical diagnosis. All patients were attended at the Hospital de Clínicas de Porto Alegre. Two of the patients had blood collected on more than one occasion during the chronic phase of the disease, and in three cases samples were collected during the chronic and the subsequent acute phase. Eleven of the patients were females and 22 were males, with a mean age of 36.5 years (12-60 years) at diagnosis. Most of the patients received conventional chemoterapy (hydroxyurea or busulfan), and 10 of them were treated with interferon$\alpha$ for less than 6 months, without karyotypic remission.

Mononuclear cells were prepared from peripheral blood samples using a Ficoll-Hypaque (Histopaque, Sigma Chemical Co., St. Louis, MO) gradient. The cells were stored in liquid nitrogen prior to use.

\section{Nucleic acid preparation and reverse transcription}

Total cellular RNA was extracted from frozen cells with Trizol (Gibco BRL, Grand Island, NY) according to the manufacturer's instructions. The RNA was resuspended in $20 \mu \mathrm{l}$ of sterile water treated with diethylpyrocarbonate (DEPC, Sigma). cDNA was generated from $8 \mu \mathrm{l}$ of total RNA, using random hexamers and a first strand cDNA synthesis kit (Pharmacia Biotech, São Paulo, SP, Brazil).

\section{Polymerase chain reaction (PCR)}

The reaction mixture contained $2.5 \mu \mathrm{cDNA}$ and 
$100 \mu \mathrm{M}$ of each dNTP, $10 \mathrm{mM}$ Tris- $\mathrm{HCl}, \mathrm{pH} 8.3,1.5 \mathrm{mM}$ $\mathrm{MgCl}_{2}, 2.5 \mathrm{U}$ Taq polymerase (Cenbiot/RS, Porto Alegre $\mathrm{RS}$, Brazil) and $1 \mu \mathrm{M}$ of each primer in a final volume of $25 \mu \mathrm{l}$. The antisense primer derived from exon a2 of ABL was 5'CTCCACTGGCCACAAAAT3' and the sense primer derived from exon b2 of M-bcr was 5'TTCAGAAGCT TCTCCCTG3' (Lion et al., 1991). The samples were overlain with mineral oil followed by 35 cycles of PCR in a Pharmacia thermocycler. DNA was denatured by initially heating the samples at $93^{\circ} \mathrm{C}$ for $2 \mathrm{~min}$, and then for $40 \mathrm{~s}$ in subsequent cycles. Primers were allowed to anneal at $60^{\circ} \mathrm{C}$ for $30 \mathrm{~s}$ and strand extension was done at $72^{\circ} \mathrm{C}$ for $40 \mathrm{~s}$, with a final extension step of $7 \mathrm{~min}$. An aliquot (0.5-2.5 $\mu \mathrm{l})$ from this first amplification was further amplified by a second round of PCR using $1 \mu \mathrm{M}$ of the primer from exon b2 of M-bcr (5'TTCAGAAGCTTCTCCCTGACATCCG3') and exon a 2 of ABL (5'CTCCACTGGCCACAAAAT CATACAG3') (Trka et al., 1995). The reaction conditions for this second round of amplification involved: initial denaturation $(2 \mathrm{~min})$ at $93^{\circ} \mathrm{C}$ followed by 35 cycles of denaturation at $93^{\circ} \mathrm{C}$ for $40 \mathrm{~s}$, annealing at $60^{\circ} \mathrm{C}$ for $40 \mathrm{~s}$, and extension at $72^{\circ} \mathrm{C}$ for $1 \mathrm{~min}$ with a final extension step at $72^{\circ} \mathrm{C}$ for $7 \mathrm{~min}$. A negative control (water instead of cDNA) was included in all reactions. All samples were amplified on at least two different occasions in order to confirm the results. In cases where no amplification was obtained during the first round of PCR, the cDNA was tested in a PCR with $\beta$-actin primers (Schulze et al., 1995) (control) to assess the integrity of the RNA molecule.

Aliquots $(8 \mu \mathrm{l})$ of the PCR products were run on $2 \%$ nucleic acid (NA) agarose (Pharmacia Biotech) gels containing ethidium bromide and molecular weight markers (100-base pair ladder; Pharmacia Biotech). The primers used in the two rounds of PCR specified a 327-bp fragment from the b3a2 mRNA, and a 246-bp fragment in the absence of exon b3.

\section{Statistical analysis}

The patients were separated into two groups (presence or absence of exon b3), and association with clinical and hematological parameters was analyzed using the $\chi^{2}$ test or Fisher exact test for categorical parameters and Student's $t$-test or the Mann-Whitney test for continuous parameters. Parameters included age, sex, hemoglobin measurement, white blood cell and platelet counts, and percentage of blasts and basophils. Spleen size (expressed as the increase as compared to normal size) and Sokal index (see Introduction) were also included. Data were not available for some of the patients. The duration of the chronic phase was calculated from the date of diagnosis to the date of the accelerated or acute phase. The definition of chronic and acute phases followed the criteria described by Kantarjian et al. (1990). In nine of the 33 cases, a cytological analysis was also done during the acute phase of the disease. b3a2 mRNA was observed in three of these nine cases, whereas in five b2a 2 mRNA was seen and in one both types of mRNA were detected. A combined study was conducted in which the results reported by others were included. Only studies in which the type of mRNA was determined by tests with a sensitivity similar to that employed in the present study, i.e., two consecutive rounds of PCR or one round with the use of radioactive probes to detect the amplified fragments, were considered. Data from the following reports were used in our search for associations between mRNA type and clinical parameters: Yin et al. (1995) and Shepherd et al. (1995) for the Sokal index, 123 cases; Yin et al. (1995) and Gaiger et al. (1995), for age at diagnosis, 35 cases; Ponzetto et al. (1990), Nakamura et al. (1991), Shepherd et al. (1995), Gaiger et al. (1995), Yin et al. (1995), and Tanaka et al. (1996), for sex, 181 cases; Hooberman et al. (1989), Morgan et al. (1990), Ponzetto et al. (1990), Nakamura et al.(1991), Fioretos et al. (1993) and Tanaka et al. (1996) for cell lineage, 43 cases.

\section{RESULTS}

The conditions for RT-PCR established in this work provided excellent amplification of cDNA from BCR/ABL mRNA. The material analyzed included samples from 33 patients, 25 collected in the chronic phase and 13 in the accelerated phase of the disease. In cases where more than one sample was tested on different occasions during the chronic phase (two patients), or in the chronic and subsequent accelerated phase (three patients), there was no alteration in the type of transcript obtained. b3a2 mRNA was detected in samples from 14 of the CML patients, whereas b2a2 mRNA was observed in 13 cases and six patients had both types of transcripts. BCR/ABL mRNA was detected after the first round of PCR in all cases except for one in which the mononuclear cells showed a low viability. In four of the six cases with both types of transcripts, the second type was observed only after the second round of PCR.

There were no significant associations between mRNA type and hematological or clinical parameters at diagnosis, or the duration of the chronic phase (Table I). A combined analysis including our results and those reported in the literature showed that the only significant association was between mRNA type and sex (Table II), with a predominance of men in the groups expressing b2a 2 (2.68:1) and b3a2 (1.33:1).

\section{DISCUSSION}

RT-PCR is widely used for studying the hybrid gene BCR/ABL in CML. The specificity of the amplification reaction can be confirmed by hybridization with labelled probes. This was not necessary in the present study as most of the samples were also sequenced in a parallel study (Meissner et al., 1998). Since primers for exons b2 and a2 
Table I - Association between clinical and laboratory data and the type of mRNA for the 33 chronic myeloid leukemia patients.

\begin{tabular}{|c|c|c|c|c|c|c|c|}
\hline \multirow[t]{2}{*}{ Parameters $^{1}$} & \multicolumn{3}{|c|}{ Type of mRNA } & \multicolumn{2}{|c|}{ No. of cases } & \multirow[t]{2}{*}{ Stat $^{2}$} & \multirow[t]{2}{*}{$P$} \\
\hline & b3a2 & $\mathrm{b} 2 \mathrm{a} 2$ & Total & b3a2 & $\mathrm{b} 2 \mathrm{a} 2$ & & \\
\hline Age, years & $\begin{array}{c}35.7 \\
(12-60)\end{array}$ & $\begin{array}{c}37.5 \\
(13-50)\end{array}$ & $\begin{array}{c}36.5 \\
(12-60)\end{array}$ & 20 & 13 & S & 0.663 \\
\hline $\operatorname{Sex}(M / F)$ & $11 / 9$ & $11 / 2$ & $22 / 11$ & $11 / 9$ & $11 / 2$ & $\mathrm{~F}$ & 0.132 \\
\hline $\begin{array}{l}\mathrm{Hb} \\
(\mathrm{g} / \mathrm{dl})\end{array}$ & $\begin{array}{c}10.1 \\
(7.7-13.4)\end{array}$ & $\begin{array}{c}10.5 \\
(8.4-12.6)\end{array}$ & $\begin{array}{c}10.7 \\
(7.7-14.3)\end{array}$ & 14 & 10 & S & 0.671 \\
\hline $\begin{array}{l}\text { WBC } \\
\left(\mathrm{x} 10^{-3} / \mu \mathrm{l}\right)\end{array}$ & $\begin{array}{c}125.4 \\
(31-446)\end{array}$ & $\begin{array}{c}116.7 \\
(15-283)\end{array}$ & $\begin{array}{c}112.2 \\
(15-446)\end{array}$ & 18 & 10 & MW & 0.943 \\
\hline $\begin{array}{l}\text { Platelets } \\
\left(\mathrm{x} 10^{-3} / \mu \mathrm{l}\right)\end{array}$ & $\begin{array}{c}475.6 \\
(117-910)\end{array}$ & $\begin{array}{c}346.5 \\
(180-714)\end{array}$ & $\begin{array}{c}429.4 \\
(117-910)\end{array}$ & 18 & 10 & MW & 0.163 \\
\hline Blasts (\%) & $4.8(0-28)$ & $3.0(0-10)$ & $4.1(0-28)$ & 18 & 10 & MW & 0.408 \\
\hline Basophils (\%) & $4.0(0-13)$ & $3.0(0-10)$ & $2.8(0-13)$ & 18 & 10 & MW & 0.734 \\
\hline Spleen size $(\mathrm{cm})^{3}$ & $8.1(0-18)$ & $8.3(0-16)$ & $5.5(0-18)$ & 12 & 7 & $\mathrm{~S}$ & 0.945 \\
\hline Sokal index & $\begin{array}{c}1.07 \\
(0.56-1.72)\end{array}$ & $\begin{array}{c}0.85 \\
(0.63-1.10)\end{array}$ & $\begin{array}{c}1.32 \\
(0.56-1.10)\end{array}$ & 12 & 7 & $S$ & 0.172 \\
\hline Duration CP (months) & $29.9(0-85)$ & $12.5(0-27)$ & $23.2(0-85)$ & 11 & 7 & MW & 0.084 \\
\hline
\end{tabular}

${ }^{1}$ Clinical and laboratory data are reported as averages with the range in parentheses. $\mathrm{CP}$, Chronic phase; Hb, hemoglobin; WBC, white blood cell count. ${ }^{2}$ Statistical test: F, Fisher exact test; MW, Mann-Whitney; S, Student's $t$-test. All $\mathrm{P}$ values are two-tailed. ${ }^{3}$ From costal margin.

Table II - Analysis of the association between clinical and laboratory data and the type of mRNA for the chronic myeloid leukemia patients in this study combined with data from the literature (for references, see text - Statistical analysis).

\begin{tabular}{|c|c|c|c|}
\hline \multirow[t]{2}{*}{ Parameters } & \multicolumn{2}{|c|}{ Type of mRNA } & \multirow[t]{2}{*}{ Statistical analysis } \\
\hline & b3a2 & $\mathrm{b} 2 \mathrm{a} 2$ & \\
\hline \multicolumn{4}{|l|}{ Age } \\
\hline $\mathrm{N}$ & 43 & 25 & \multirow{3}{*}{ Student's $t$-test: $\mathrm{P}=0.773$} \\
\hline Mean (years) & 40 & 41 & \\
\hline Range (years) & $2-65$ & $13-65$ & \\
\hline \multicolumn{4}{|c|}{ Sokal risk group $(\mathrm{N})$} \\
\hline Low & 16 & 17 & \multirow{3}{*}{$\begin{array}{l}\chi^{2} \text { test }(\text { Yates })=5.99 ; \text { d.f. }=2 \\
P=0.066\end{array}$} \\
\hline Intermediate & 41 & 25 & \\
\hline High & 32 & 11 & \\
\hline \multicolumn{4}{|l|}{$\operatorname{Sex}(N)$} \\
\hline Female & 57 & 22 & \multirow{2}{*}{$\begin{array}{l}\chi^{2} \text { test }(\text { Yates })=4.67 ; \text { d.f. }=1 ; \\
P=0.029\end{array}$} \\
\hline Male $(*)$ & 76 & 59 & \\
\hline \multicolumn{4}{|c|}{ Type of blastic crisis $(\mathrm{N})$} \\
\hline Myeloid & 10 & 11 & \multirow{2}{*}{$\begin{array}{l}\chi^{2} \text { test }(\text { Yates })=1.12 ; \text { d.f. }=1 ; \\
P=0.29\end{array}$} \\
\hline Lymphoid & 13 & 9 & \\
\hline
\end{tabular}

$\mathrm{N}=$ number of cases. ${ }^{*}$ Statistically significant association.

were used, the technique is not appropriate for the identification of mRNA with an e1a2 junction or for the rare cases where the breakpoint is outside M-bcr.

Biernaux et al. (1995) developed a highly sensitive nested PCR for detecting residual CML. Under conditions of high stringency and strict control for false positives, this assay was able to detect BCR/ABL mRNA in normal individuals. Some important differences between healthy persons and patients with CML ensure that under normal conditions RT-PCR is adequate for the diagnosis of CML. In the study by Biernaux et al. (1995), mRNA was extracted from cells in $100 \mathrm{ml}$ of blood compared to the 1-5 ml generally used for patients. In normal persons, the BCR/ABL gene was detected only after the second round of PCR, whereas for CML patients one round was sufficient in most cases. Finally, the concentration of BCR/ ABL mRNA in CML patients is of 5-6 transcripts per cell (van Rhee et al., 1996), whereas Biernaux et al. (1995) found a concentration of 5-20 transcripts per 5-10 x $10^{7}$ normal cells.

Molecular analysis of the Philadelphia chromosome in CML has shown that, independent of the location of the M-bcr breakpoint, the hybrid BCR/ABL gene can give rise to two main types of $8.5 \mathrm{~kb}$ mRNA which differ by the 
presence of exon b3 (Nakamura et al., 1991; Mills et al., 1991b). It is not known whether this difference is reflected in the properties of the hybrid protein or in the disease phenotype. Several studies, including this one, have shown that classifying CML according to mRNA type does not produce homogeneous clinical or hematological data. Although the variance of each parameter was large among patients for each mRNA type, there were no significant differences between the groups, except for the duration of the chronic phase for which the variance in the b3a2 group was greater than in the $\mathrm{b} 2 \mathrm{a} 2$ group $(\mathrm{P}<0.05)$. Patients in the accelerated or acute phase at diagnosis were not considered in the analysis.

Considerable variation in the parameters within each group has been reported in other studies which have investigated a correlation between mRNA type or DNA breakpoint region and the clinical or hematological parameters at diagnosis. Morris et al. (1990) combined their results with those of Shtalrid et al. (1988) and observed that patients with breakpoints at 5' M-bcr had a significantly higher tendency to develop myeloid blast crisis, whereas a 3' M-bcr breakpoint was associated with lymphoid blast crisis. This association was not confirmed by Martinelli et al. (1991) when their results were analyzed together with those of other studies.

Most investigations have sought for an association between the cell line expanded during the blast crisis and breakpoints in the $3^{\prime}$ or $5^{\prime}$ regions of M-bcr. To our knowledge, no study had analyzed the association between blast crisis and the type of mRNA involved. The combined analysis of our results with those of others (total of 43 cases) showed no predominance of either of the two mRNA types in myeloid or lymphoid blast crisis. However, there was an association between the type of mRNA and sex $(\mathrm{P}=0.029)$, but we have no explanation for this at the moment.

The clinical heterogeneity of CML patients at diagnosis seems to be dependent on the time at which medical care is sought. As with many other diseases, the socioeconomic status, geographic localization of the patient and other cultural factors influence when medical care is sought and the clinical situation at diagnosis. Thus, patients with less aggressive forms of the disease may seek for help later when the disease is more advanced. If differences determined by exon $\mathrm{b} 3$ of the hybrid BCR/ABL gene play a role in the progress, they are apparently not strong enough to be seen at this level.

It is possible that the intron region near exon b3, rather than exon b3 itself, has a role in the pathogenesis of CML, as suggested by the high frequency of breaks at this site. The intron sequences of M-bcr near b3 exon have been shown to possess tissue-specific transcription suppressors (Stewart et al., 1994), and cells from CML patients have patterns of methylation different from those of normal cells (Litz et al., 1992, 1996). The inclusion or exclusion of intron structures in the hybrid gene may thus be associated with the regulation of oncogene expression and heterogeneity of the disease. Studies in which patients were classified according to the location of the M-bcr breakpoint relative to a randomly selected central HindIII site (see Mills et al., 1991a) generally did not consider how many of these regulatory elements were included in the hybrid BCR/ABL gene. We believe that a better understanding of the regulation and functioning of the $\mathrm{BCR}$ and $\mathrm{ABL}$ genes during cell differentiation in normal hematopoiesis will help to elucidate their role in leukemogenesis.

\section{ACKNOWLEDGMENTS}

Publication supported by FAPESP.

\section{RESUMO}

Neste trabalho foi analisado por RT-PCR o tipo de junção no mRNA BCR/ABL híbrido, que caracteriza a leucemia mielóide crônica (CML), em material proveniente de 33 pacientes (22 homens e 11 mulheres). Em 14 dos casos $(42,4 \%)$ foi observado mRNA do tipo b3a2, em $13(39,4 \%)$ mRNA b2a 2 e em $6(18,2 \%)$ ambos os tipos, mas com predomínio de b3a2. Não foram observadas correlações estatisticamente significantes entre tipo de mRNA e idade, teor de hemoglobina, contagem de leucócitos e plaquetas, porcentagem de blastos ou basófilos e esplenomegalia, todos ao diagnóstico, assim como sexo do paciente ou duração da fase crônica. Foram realizadas ainda análises combinando os dados obtidos neste estudo com outros publicados para os seguintes parâmetros: idade ao diagnóstico, índice Sokal, sexo e linhagem celular da crise blástica. Apenas no estudo combinado sexo $\mathrm{X}$ tipo de mRNA foi verificada associação estatisticamente significante $(\mathrm{P}=0,029)$, com predominância de homens nos grupos que expressam b2a2 (2,68:1) e b3a2 (1,33:1). Conclui-se que a categorização dos pacientes quanto ao tipo de mRNA não homogeneiza os dados clínicos e hematológicos dentro de cada grupo, onde a variância é grande, nem os diferencia.

\section{REFERENCES}

Biernaux, C., Loos, M., Sels, A., Huez, G. and Stryckmans, P. (1995). Detection of major BCR/ABL gene expression at a very low level in blood cells of some healthy individuals. Blood 86: 3118-3122.

Fioretos, T., Nilsson, P.-G., Aman, P., Heim, S., Kristoffersson, U., Maim, C., Simonsson, B., Turesson, I. and Mitelman, F. (1993). Clinical impact of breakpoint position within M-bcr in chronic myeloid leukemia. Leukemia 7: 1225-1231.

Gaiger, A., Henn, T., Horth, E., Geissler, K., Mitterbauer, G., MaierDobersberger, T., Greinix, H., Mannhalter, C., Haas, O.A., Lechner, K. and Lion, T. (1995). Increase of BCR/ABL chimeric mRNA expression in tumor cells of patients with chronic myeloid leukemia precedes disease progression. Blood 86: 2371-2378.

Hooberman, A.L., Carrine, J.J., Leibowitz, D., Rowley, J.D., Le Beau, M.M., Arlin, Z.A. and Westbrook, C.A. (1989). Unexpected heterogeneity of BCR/ABL fusion mRNA detected by polymerase chain reaction in Philadelphia chromosome-positive acute lymphoblastic leukemia. Proc. Natl. Acad. Sci. USA 86: 4259-4263.

Inokuchi, K., Inoue, T., Tojo, A. and Futaki, M. (1991). A possible correlation between the type of BCR-ABL hybrid messenger RNA and platelet count in Philadelphia-positive chronic myelogenous 
leukemia. Blood 78: 3125-3127.

Kantarjian, H.M., Keating, M.J., Smith, T.I., Talpaz, M. and McCredie, K.B. (1990). Proposal for a simple synthesis prognostic staging system in chronic myelogenous leukemia. Am. J. Med. 88: 1-8.

Lion, T., Prischl, F., Haas, O.A., Pont, J. and Schwarzmeier, J. (1991). Non-radioactive detection of the rearranged BCR/ABL sequences amplified by polymerase chain reaction. Leukemia 5: 156-159.

Litz, C.E., McClure, J.S., Coad, J.E., Goldfarb, A.N. and Brunning, R.D. (1992). Methylation status of the major breakpoint cluster region in Philadelphia chromosome negative leukemias. Leukemia 6: $35-41$.

Litz, C.E., Vos, J.A. and Copenhaver, C.M. (1996). Aberrant methylation of the major breakpoint cluster region in chronic myeloid leukemia. Blood 88: 2241-2249.

Lugo, T.G., Pendergast, A.-M., Muller, A.J. and Witte, O.N. (1990). Tyrosine kinase activity and transformation potency of bcr-abl oncogene products. Science 247: 1079-1082.

Martinelli, G., Chiamenti, A., Gasparini, P., Pignati, P.F., Ambrosetti, A., Zaccaria, A., Buzzi, M., Testoni, N., Tura, S., Guerrasio, A., Rosso, C. and Saglio, G. (1991). Bcr breakpoint subregions and blast crisis lineage in CML patients. Br. J. Haematol. 79 (Suppl. 1): 838-839.

Meissner, R.V., Dias, P.M.B., Covas, D.T., Job, F.M., Leite, M. and Nardi, N.B. (1998). A polymorphism in exon b2 of the major breakpoint cluster region (M-bcr) identified in chronic myeloid leukaemia patients. Br. J. Haematol. 103: 224-226.

Mills, K.I., Benn, P. and Birnie, G.D. (1991a). Does the breakpoint within the major breakpoint cluster region (M-bcr) influence the duration of the chronic phase in chronic myeloid leukemia? An analytical comparison of current literature. Blood 78: 1151-1161.

Mills, K.I., Sproul, A.M., Leibowitz, D. and Burnett, A.K. (1991b). Mapping of breakpoints and relationship to BCR-ABL RNA expression in Philadelphia chromosome-positive chronic myeloid leukemia patients with a breakpoint around exon 14 (b3) of the BCR gene. Leukemia 5: 937-941.

Morgan, G.J., Hernandez, A., Chan, L.C., Martiat, T. and Wiedmann, L.M. (1990). The role of alternative splicing patterns of BCR/ABL transcripts in the generation of blast crisis of chronic myeloid leukemia. Br. J. Haematol. 76: 33-38.

Morris, S.W., Daniel, L., Ahmed, C.M., Elias, A. and Lebowitz, P. (1990). Relationship of bcr breakpoint to chronic phase duration, survival, and blast crisis lineage in chronic myelogenous leukemia patients presenting in early chronic phase. Blood 75: 2035-2041.

Nakamura, K., Miyashita, T., Ozaki, M. and Iwaya, M. (1991). Molecular studies of chronic myelogenous leukemia using the polymerase chain reaction. Cancer 68: 2426-2430.

Ponzetto, C., Guerrasio, A., Rosso, C., Avanzi, G. and Tassinari, A. (1990). ABL proteins in Philadelphia-positive acute leukaemias and chronic myelogenous leukaemia blast crisis. Br. J. Haematol. 76: $39-44$.

Schulze, E., Krahl, R., Thalmeier, K. and Helbig, W. (1995). Detection of $\mathrm{BCR} / \mathrm{ABL}$ mRNA in single progenitor colonies from patients with chronic myeloid leukemia by PCR: Comparison with cytogenetics and PCR from uncultured cells. Exp. Hematol. 23: 1649-1654.
Shepherd, P., Suffolk, R., Halsey, J. and Allan, N. (1995). Analysis of molecular breakpoint and m-RNA transcripts in a prospective randomized trial of interferon in chronic myeloid leukaemia: no correlation with clinical features, cytogenetic response, duration of chronic phase, or survival. Br. J. Haematol. 89: 546-554.

Shtalrid, M., Talpaz, M., Kurzrock, R., Kantarjian, H. and Trujillo, J. (1988). Analysis of breakpoints within the bcr gene and their correlation with the clinical course of Philadelphia-positive chronic myelogenous leukemia. Blood 72: 485-490.

Shtivelman, E., Lifshitz, B., Gale, R.P. and Canaani, E. (1985). Fused transcripts of abl and bcr genes in chronic myelogenous leukaemia. Nature 315: 550-554.

Sokal, J.E., Cox, E.B., Baccarani, M., Tura, S., Gomez, G.A., Robertson, J.E., Tso, C.Y., Braun, T.J., Clarkson, B.D., Cervantes, F., Rozman, C. and Italian Cooperative CML Study Group (1984). Prognostic discrimination in "good-risk" chronic granulocytic leukemia. Blood 63: 789-799.

Stewart, M.J., Cox, G., Reifel-Miller, A., Kim, S.Y., Westbrook, C.A. and Leibowitz, D.S. (1994). A novel transcriptional suppressor located within a downstream intron of the BCR gene. J. Biol. Chem 269: 10820-10829.

Tanaka, M., Yamazaki, Y., Hattori, M., Tsushita, K., Utsumi, M. and Yoshidas, S. (1996). The dual expression of minor and major BCR/ ABL chimeric mRNA in blast crisis of chronic myelogenous leukemia. Leuk. Res. 20: 575-580

Trka, J., Divoky, V. and Lion, T. (1995). Prevention of product carry-over by single tube two round (ST-R) PCR: application to BCR/ABL analysis in chronic myelogenous leukemia. Nucleic Acids Res. 23: 47364737.

Van Rhee, F., Hochhaus, A., Lin, F., Melo, J.V., Goldman, J.M. and Cross, N.C.P. (1996). p190 BCR/ABL mRNA is expressed at low levels in p210-positive chronic myeloid and acute lymphoblastic leukemias. Blood 87: 5213-5217.

Verschraegen, C.F., Kantarjian, H.M., Hirsch-Ginsberg, C., Lee, M.S., O’Brien, S., Rios, M.B., Stass, A.S., Keating, M. and Talpaz, M. (1995). The breakpoint cluster region site in patients with Philadelphia chromosome-positive chronic myelogenous leukemia. Cancer 76: 992-997.

Yin, J.-L., Williams, B.G., Arthur, C.K. and Ma, D.D.F. (1995). Interferon response in chronic myeloid leukaemia correlates with ABL/ BCR expression: a preliminary study. Br. J. Haematol. 89: 539-545.

Zaccaria, A., Martinelli, G., Buzzi, M., Testoni, N., Farabegoli, P., Zuffa, E., Zamagni, M.D., Russo, D., Baccarani, M., Ambrostti, A., Guerrasio, A., Saglio, A., Saglio, G. and Tura, S. (1993). The type of BCR/ABL junction does not predict the survival of patients with $\mathrm{Ph1}$-positive chronic myeloid leukaemia. Br. J. Haematol. 84: 265268.

Zaccaria, A., Martinelli, G., Testoni, N., Zuffa, E., Farabegoli, P., Russo, D., Guerrasio, A. and Tura, S. (1995). Does the type of BCR/ABL junction predict the survival of patients with chronic myeloid leukemia? Leuk. Lymph. 16: 231-236.

(Received August 13, 1998) 
